\title{
Prevalence and Determinants of Adult Obesity in a Low-Income Population of Western Africa: Results from a Nationwide Cross-Sectional Survey
}

\author{
Komlavi Yayehd ${ }^{1,2^{*}}$,Marie Paule Bernadette N'cho-Mottoh ${ }^{3}$, Soulemane Pessinaba ${ }^{1,2}$ \\ Soodougoua Baragou ${ }^{1,2}$, Tchaa Tchérou ${ }^{1,2}$, Yaovi Mignazonzon Afassinou ${ }^{2,4}$, Machihude \\ Pio $^{2,4}$, N'loo Serge Alain Essam ${ }^{5}$, Edem Goeh-Akue ${ }^{2,4}$, Findibe Damorou ${ }^{1,2}$ and Loic Belle ${ }^{6}$ \\ ${ }^{1}$ Department of cardiology, University teaching hospital of “Campus”, Lomé, Togo \\ ${ }^{2}$ National Program of Fighting against cardiovascular diseases, Togo \\ ${ }^{3}$ Institute of cardiology of Abidjan, Côte d'Ivoire \\ ${ }^{4}$ Department of cardiology, "Sylvanus Olympio" University teaching hospital, Lomé, Togo \\ ${ }^{5}$ Department of cardiology, Military Hospital of Yaoundé, Cameroon \\ ${ }^{6}$ Department of cardiology, Hospital of Annecy, Metz-Tessy, France
}

Received: April 07, 2017; Accepted: May 15, 2017; Published: May 26, 2017

*Corresponding author: Komlavi Yayehd, Department of Cardiology, Lecturer, Faculty of Health Sciences, University Teaching Hospital of "Campus", 03BP 30284, Lomé, Togo, Tel: +228 914281 55; Fax: +228 225017 68; E-mail: kyayehd@gmail.com

\begin{abstract}
Background: The prevalence of obesity is rising in low/middleincome countries. Better understanding of the epidemiological characteristics of obesity will benefit the development of prevention programs in these countries. We sought to determine the prevalence of obesity and associated factors among adults in Togo, a low-income country in Western Africa.
\end{abstract}

Design: This was a secondary analysis from a nationwide crosssectional survey conducted in September-October 2011.

Methods: The survey involved unselected respondents aged $\geq 18$ years living in Lomé (urban population) and in central Togo (semiurban population). Overweight was defined as Body Mass Index (BMI) $25-29.9 \mathrm{~kg} / \mathrm{m}^{2}$ and obesity as $\geq 30 \mathrm{~kg} / \mathrm{m}^{2}$. Central obesity was classified using National Cholesterol Education Program (NCEP) and International Diabetes Federation (IDF) definitions.

Results: Data from 2626 respondents were surveyed (1900 in Lomé, 726 in central Togo). Overall prevalence of obesity was $20.1 \%$ and overweight was $27.7 \%$. Obesity was most prevalent among subjects aged 35-64 years (Odds Ratio (OR): 2.21 (95\% Confidence Interval (CI): 1.80-2.72)). More women than men were obese (OR: 3.88 (95\% CI: 3.08-4.87)), irrespective of whether they lived in an urban or semi-urban area. Obesity was more prevalent among urban inhabitants (OR: 2.15 (95\% CI: 1.68-2.75)); this difference persisted after adjustment. The prevalence of central obesity was $33.7 \%$ with the NCEP definition, $48.8 \%$ with the IDF definition.

Conclusions: The prevalence of adult obesity in a low-income Western African population is high. Urban living, female sex and age 35-64 years were associated with obesity, suggesting that prevention programs should target these classes as a priority.

Keywords: Obesity; Prevalence; Adult; Western Africa

\section{Abbreviations}

BMI: Body Mass Index; NCEP: National Cholesterol Education Program; IDF: International Diabetes Federation; WC: Waist Circumference; WHO: World Health Organization; HIVAIDS: Human Immunodeficiency Virus and Acquired Immune Deficiency Syndrome; USA: United States of America; SD: Standard Deviation

\section{Introduction}

The prevalence of obesity in many developed countries has reached alarming proportions [1,2]. A rapid increase in the prevalence of obesity has also been reported in major emerging countries such as China [3]. In low-income populations of Western Africa, which face serious problems of malnutrition and infectious diseases including malaria, tuberculosis and HIV-AIDS, health problems related to obesity are relegated to the background. However, the World Health Organization (WHO) estimated that obesity is becoming one of the main burdens for low- and middleincome populations, because it is associated with a cluster of metabolic and cardiovascular risk factors such as hypertension, and it increases the risk of acute coronary syndromes [4,5]. Obesity is also associated with cancer and asthma, depression and osteoarthritis $[6,7]$. It increases the risk of premature death and healthcare costs $[8,9]$.

Epidemiological studies on obesity have been done in this region of Western Africa (Togo, Nigeria, Ghana). Some were conducted in selected outpatient cardiology departments, whereas others were restricted to urban or semi-urban settings only [10-15]. Few studies have focused on obesity in the general 
population, including people living in urban and semi-urban regions [16,17]. Epidemiological data could provide important information for optimizing prevention programs in these populations. The aim of the present study was to determine the prevalence of obesity and associated factors among adults in Togo, a low-income country in Western Africa.

\section{Methods}

\section{Study design}

We performed a secondary analysis of data from a nationwide cross-sectional survey on hypertension and associated risk factors in Togo, a low-income country in Western Africa [18]. The analysis included unselected respondents aged $\geq 18$ years living in an urban (Lomé) or semi-urban (central region of Togo) area, between 1 September and 14 October 2011. Unselected respondents presented to the survey sites after a week of publicity (sensitization) in local mass media (radio, television) in urban areas. In some locations of semi-urban areas, the heads of villages announced the survey through their local information committees, who highlighted the importance of participating in the survey.

The 2011 demographic statistics estimated the Togolese population to be approximately 6.1 million, with an average growth rate of $2.84 \%$ per year. The urban architecture is dominated by the city of Lomé, whose population amounts to 837,437 inhabitants. Lomé has most healthcare facilities and provides easy access to governmental and social services compared with other parts of the country. The central region of Togo, with 543,150 inhabitants, is a semi-urban area with an essentially informal economy system such as market workers and farmers [19].

\section{Data collection and procedures}

For data collection, nine sites were selected in the main districts of Lomé: Tokoin, Bè, Klikamé, Nukafu, Djidjolé, Atikoumé, Port, Cacaveli and Nyékonakpoé. Collection sites in the central region were Blitta, Tchamba and Sokodé. To limit selection bias, the study was done on different days of the week and at different times of the day. We systematically and exhaustively approached all passersby, inviting them to enroll in the study. The medical team at each site comprised two doctors and four registered nurses. To limit reproducibility bias, all members of the medical team were trained (for 1 day) on the methods of data collection. Data were available on location of residence, age, sex, profession, tobacco use (current smokers), alcohol consumption and use of hormonal contraception (among women).

Weight and height were measured using an adult hospital lever balance with participants wearing light clothing and no shoes or extra articles. Body mass index (BMI) was classified according to the WHO as underweight (BMI $<18.5 \mathrm{~kg} /$ $\mathrm{m} 2$ ), normal weight (BMI $18.5-24.9 \mathrm{~kg} / \mathrm{m}^{2}$ ), overweight (BMI $25-29.9 \mathrm{~kg} / \mathrm{m}^{2}$ ) and obese (BMI $\left.\geq 30 \mathrm{~kg} / \mathrm{m}^{2}\right)$. Severity of obesity was stratified into moderate (BMI $30-34.9 \mathrm{~kg} / \mathrm{m}^{2}$ ), severe (BMI $35-39.9 \mathrm{~kg} / \mathrm{m}^{2}$ ) and morbid (BMI $\geq 40 \mathrm{~kg} / \mathrm{m}^{2}$ ) [20].
Waist circumference was measured midway between the iliac crest and the lower-most margin of the ribs, with a bare belly and at the end of normal expiration according to the WHO guidelines [20]. Central obesity was defined by waist circumference using two definitions: (1) waist circumference $>88 \mathrm{~cm}$ for women and $>102 \mathrm{~cm}$ for men, according to the National Cholesterol Education Program (NCEP) Expert Panel on Detection, Evaluation, and Treatment of High Blood Cholesterol In Adults (Adult Treatment Panel III) classification and (2) waist circumference $>80 \mathrm{~cm}$ for women and $>94 \mathrm{~cm}$ for men, according to the International Diabetes Federation (IDF) definition $[21,22]$. Hypertension was defined as systolic blood pressure $\geq 140 \mathrm{mmHg}$ and/or diastolic blood pressure $\geq 90 \mathrm{mmHg}$ [23].

\section{Ethical Considerations}

Oral informed consent was obtained from all respondents, in accordance with the Declaration of Helsinki. The study was approved by the National Ethics Committee. Each respondent's answers and medical data were kept confidential. After screening, advice was provided to all respondents, some of whom were referred to hospital for treatment.

\section{Statistical Analysis}

Continuous variables are presented as mean \pm Standard Deviation (SD) and categorical variables as count and percentage. The chi-square test was used to compare categorical variables and the $t$ test was used for continuous variables. Univariate logistic regression analysis was used to determine the relationship between obesity and socio demographic factors (sex, location) [3]. Appropriate adjustment for potential confounders (e.g. age, sex, location of residence, tobacco use, alcohol consumption and use of hormonal contraception) was made in multiple logistic regression analysis. All tests were two-sided and $p<0.05$ was considered statistically significant [24-26].

Anticipating that the prevalence of obesity would be $25 \%$, a confidence interval of $23 \%$ to $27 \%$ was determined as clinically relevant. Thus, a sample size of 2000 respondents would be needed (Wald method) [11].

All statistical analyses were performed using Centers for Disease Control and Prevention (CDC) Epi-Info version 7 software.

\section{Results}

Among the 2749 respondents surveyed, 123 had missing anthropometric data and were excluded from the analysis, leaving a population of 2626 subjects. Of these, 1900 were living in Lomé (an urban area) and 726 were living in the central region of the country (semi-urban area).

Table 1 shows the comparison of the baseline characteristics of urban and semi-urban inhabitants and according to sex. Urban inhabitants was younger than semiurban ones ( $40.9 \pm 14.0$ vs $47.0 \pm 16.6$ years; $p<0,001$ ), whereas women were older than men ( $43.8 \pm 15.5$ vs $40.9 \pm 14.2$ years; $p$ $<0,001)$. There were more manual workers among semi-urban inhabitants and among men (each $\mathrm{p}<0.001$ ), while there were 
Table 1: Baseline characteristics, overall and according to residence and gender

\begin{tabular}{|c|c|c|c|c|c|c|c|}
\hline & \multirow{2}{*}{$\begin{array}{l}\text { Total population } \\
\quad(n=2626)\end{array}$} & \multicolumn{3}{|c|}{ By residence } & \multicolumn{3}{|c|}{ By sex } \\
\hline & & $\begin{array}{c}\text { Urban } \\
(n=1900)\end{array}$ & $\begin{array}{l}\text { Semi-urban } \\
(n=726)\end{array}$ & $P$ & $\begin{array}{l}\text { Women } \\
(n=1479)\end{array}$ & $\begin{array}{c}\text { Men } \\
(n=1147)\end{array}$ & $p$ \\
\hline Men, $n(\%)$ & $1147(43.7)$ & $872(45.9)$ & 275 (37.9) & 0.0002 & 0 & $1147(100)$ & - \\
\hline $\begin{array}{c}\text { Age (years), mean } \\
\pm \text { SD }\end{array}$ & $42.6 \pm 15.0$ & $40.9 \pm 14.0$ & $47.0 \pm 16.6$ & $<0.0001$ & $43.8 \pm 15.5$ & $40.9 \pm 14.2$ & $<0.0001$ \\
\hline \multicolumn{8}{|l|}{ Age group, $n$ (\%) } \\
\hline $18-24$ years & $293(11.2)$ & $225(11.8)$ & $68(9.4)$ & 0.07 & $154(10.4)$ & 139 (12.1) & 0.16 \\
\hline $25-34$ years & $618(23.5)$ & $507(26.7)$ & $111(15.3)$ & $<0.0001$ & $312(21.1)$ & $306(26.7)$ & 0.0008 \\
\hline $35-44$ years & $571(21.7)$ & $419(22.1)$ & $152(20.9)$ & 0.53 & $312(21.1)$ & $259(22.6)$ & 0.36 \\
\hline $45-54$ years & $542(20.6)$ & $385(20.3)$ & 157 (21.6) & 0.44 & $320(21.6)$ & $222(19.4)$ & 0.15 \\
\hline $55-64$ years & 359 (13.7) & $243(12.8)$ & $116(16.0)$ & 0.03 & $221(14.9)$ & $138(12.0)$ & 0.03 \\
\hline $65-74$ years & 177 (6.7) & $99(5.2)$ & 78 (10.7) & $<0.0001$ & $110(7.4)$ & $67(5.8)$ & 0.10 \\
\hline$\geq 75$ years & $66(2.5)$ & $22(1.2)$ & $44(6.1)$ & $<0.0001$ & $50(3.4)$ & $16(1.4)$ & 0.001 \\
\hline \multicolumn{8}{|l|}{ Profession, $n(\%)$} \\
\hline Manual worker & $848(32.3)$ & $455(23.9)$ & $393(54.1)$ & $<0.0001$ & $446(30.2)$ & $402(35.0)$ & 0.007 \\
\hline Informal activity & $786(29.9)$ & $682(35.9)$ & $104(14.3)$ & $<0.0001$ & $727(49.2)$ & $59(5.1)$ & $<0.0001$ \\
\hline Soldier/police & $52(1.9)$ & $16(0.8)$ & $36(5.0)$ & $<0.0001$ & $2(0.1)$ & $50(4.4)$ & $<0.0001$ \\
\hline Student & $251(9.6)$ & $213(11.2)$ & $38(5.2)$ & $<0.0001$ & $87(5.9)$ & $164(14.3)$ & $<0.0001$ \\
\hline Employee & $543(20.7)$ & $412(21.7)$ & $131(18.0)$ & 0.03 & $177(12)$ & $366(31.9)$ & $<0.0001$ \\
\hline Retired & $118(4.5)$ & $105(5.5)$ & $13(1.8)$ & $<0.0001$ & $27(1.8)$ & $91(7.9)$ & $<0.0001$ \\
\hline Unemployed & $28(1.1)$ & $17(0.9)$ & $11(1.5)$ & 0.16 & $13(0.9)$ & $15(1.3)$ & 0.28 \\
\hline \multicolumn{8}{|l|}{ Lifestyle, $n(\%)$} \\
\hline Tobacco use & $83(3.2)$ & $54(2.8)$ & $29(4.0)$ & 0.12 & $21(1.4)$ & $62(5.4)$ & 0.001 \\
\hline $\begin{array}{c}\text { Alcohol } \\
\text { consumption }\end{array}$ & $835(31.8)$ & $687(36.2)$ & $148(20.4)$ & $<0.0001$ & $382(25.8)$ & $453(39.5)$ & $<0.0001$ \\
\hline $\begin{array}{c}\text { Hormonal } \\
\text { contraception }\end{array}$ & $99(6.7)$ & $94(9.1)$ & $5(1.1)$ & $<0.0001$ & $99(6.7)$ & - & - \\
\hline \multicolumn{8}{|c|}{ Blood pressure, mean \pm SD } \\
\hline SBP (mmHg) & $134.3 \pm 28.3$ & $133.4 \pm 27.5$ & $136.8 \pm 30.1$ & 0.009 & $135.5 \pm 30.3$ & $132.8 \pm 25.3$ & 0.01 \\
\hline DBP (mmHg) & $83.1 \pm 17.5$ & $83.0 \pm 17.8$ & $83.2 \pm 16.6$ & 0.42 & $82.9 \pm 18.0$ & $83.3 \pm 16.7$ & 0.53 \\
\hline Hypertension, ${ }^{\mathrm{b}} n(\%)$ & $988(37.6)$ & $725(38.2)$ & $263(36.2)$ & 0.41 & $603(40.8)$ & $385(33.6)$ & 0.0001 \\
\hline \multicolumn{8}{|c|}{ Anthropometric parameters, mean \pm SD } \\
\hline Weight $(\mathrm{kg})$ & $69.2 \pm 14.6$ & $70.5 \pm 14.6$ & $65.7 \pm 14.1$ & $<0.0001$ & $68.8 \pm 15.9$ & $69.8 \pm 12.7$ & 0.09 \\
\hline Height (m) & $1.64 \pm 0.09$ & $1.64 \pm 0.09$ & $1.64 \pm 0.09$ & 0.06 & $1.59 \pm 0.07$ & $1.70 \pm 0.07$ & $<0.0001$ \\
\hline BMI $\left(\mathrm{kg} / \mathrm{m}^{2}\right)$ & $25.7 \pm 5.4$ & $26.2 \pm 5.5$ & $24.5 \pm 5.0$ & $<0.0001$ & $27.0 \pm 6.0$ & $24.0 \pm 4.1$ & $<0.0001$ \\
\hline $\begin{array}{l}\text { Waist } \\
\text { circumference } \\
\quad(\mathrm{cm})\end{array}$ & $84.9 \pm 19.5$ & $88.3 \pm 14.8$ & $74.1 \pm 27.3$ & $<0.0001$ & $86.9 \pm 20.5$ & $82.4 \pm 19.8$ & $<0.0001$ \\
\hline \multicolumn{8}{|c|}{$\begin{array}{l}\text { SD: Standard Deviation; SBP: Systolic Blood Pressure; DBP: Diastolic Blood Pressure; BMI: Body Mass Index } \\
\text { aData for women only } \\
\text { 'SBP } \geq 140 \mathrm{mmHg} \text { and/or DBP } \geq 90 \mathrm{mmHg} \text {. }\end{array}$} \\
\hline
\end{tabular}

more employees among urban inhabitants and men $(\mathrm{p}=0.03$ and $<0.0001$, respectively). Alcohol consumption and use of hormonal contraception were more prevalent in the urban population (both $\mathrm{p}<0.0001$ ). Men used alcohol and tobacco more often than women ( $p=0.001$ and $<0.0001$, respectively). Higher mean BMI and higher mean waist circumference were noticed among urban population (all p < 0.0001) and among women (all p < 0.0001).

The overall prevalence of obesity was $20.1 \%$ $(529 / 2626)$ and that of overweight was $27.7 \%$ (728/2626). The distribution of obesity according to age groups showed that most 


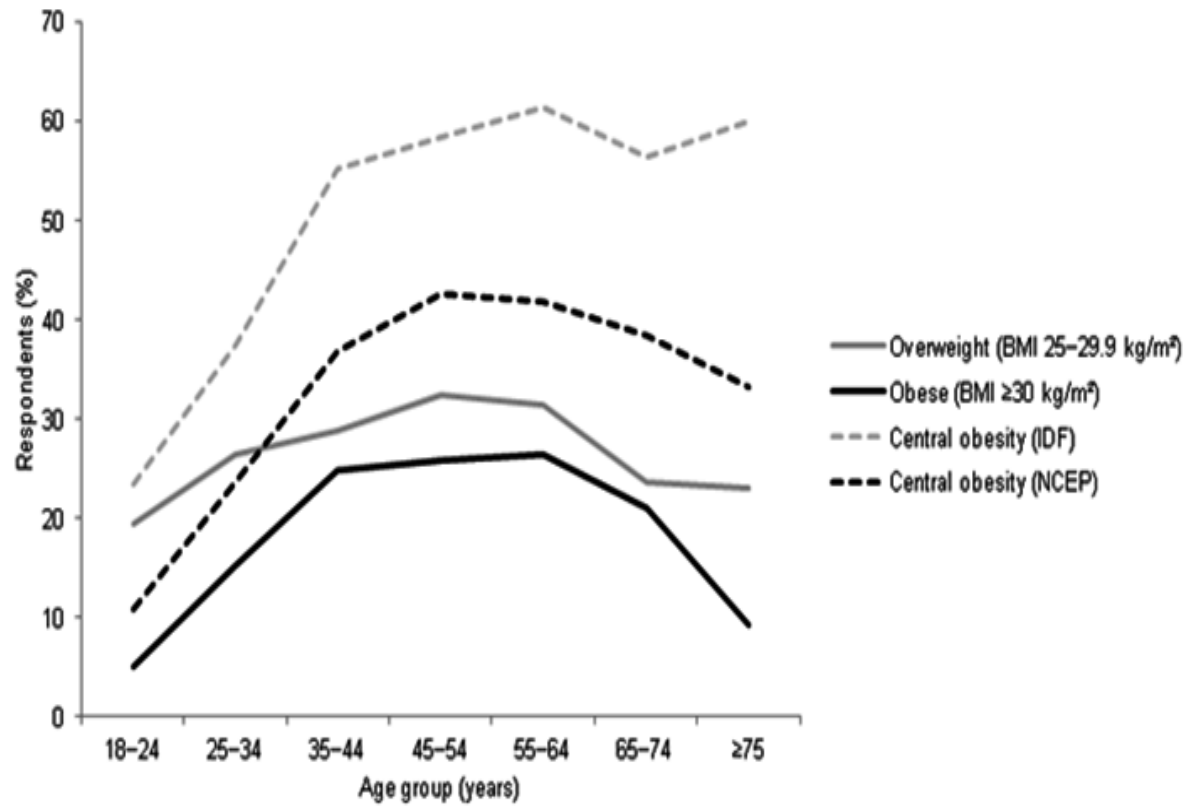

Figure 1: Prevalence of overweight (BMI $25-29.9 \mathrm{~kg} / \mathrm{m}^{2}$ ), obesity (BMI $\geq 30 \mathrm{~kg} / \mathrm{m}^{2}$ ) and central obesity in different age groups in Togo, a low-income country in Western Africa.

BMI: Body Mass Index; IDF: International Diabetes Federation; NCEP: National Cholesterol Education Program

obese people aged between 35 and 64 years (Figure 1).

In univariate logistic regression analysis, factors most associated with obesity were urban area, female sex and age 35-64 years (Table 2).

The anthropometric data, based on urban or semiurban area, are shown in Table 3. Obesity was more prevalent in the urban population $(\mathrm{p}<0.0001)$, whereas underweight $(7.9 \%$ vs $3.2 \%, \mathrm{p}<0.001)$ and normal BMI (51.7\% vs $46.1 \%, \mathrm{p}=0.01)$ were more common in the semi-urban population. This difference in the prevalence of obesity persisted after adjustment for age, sex, tobacco use, alcohol consumption and use of hormonal contraception. Moderate (15.9\% vs $8.8 \%, \mathrm{p}<0.0001)$ and severe obesity $(5.3 \%$ vs $2.1 \%, p=0.0002)$ were more prevalent in the urban population, but there was no significant difference in the distribution of morbid obesity ( $1.9 \%$ vs $1.4 \%, \mathrm{p}=0.46$ ) between the urban and semi-urban populations. The overall prevalence of central obesity was $33.7 \%$ based on the NCEP definition, $48.8 \%$ according to the IDF definition (Table 3).

Women were significantly more likely to be obese $(\mathrm{p}<$ 0.0001 ) and presented with higher rates of obesity at all levels of severity. Women had higher levels of central obesity than men for both the IDF and the NCEP definitions (all $p<0.0001$ ).

Table 2: Univariate logistic regression analysis between obesity and associated factors

\begin{tabular}{|c|c|c|c|c|}
\hline Variable & $\begin{array}{c}\text { Obese } \\
\text { (BMI } \mathbf{3 0} \mathbf{~ k g} / \mathbf{m}^{\mathbf{2}} \mathbf{)}(\mathbf{n}=\mathbf{5 2 9})\end{array}$ & $\begin{array}{c}\text { Non-obese } \\
\left(\mathbf{B M I}<\mathbf{3 0} \mathbf{~ k g} / \mathbf{m}^{\mathbf{2}} \mathbf{( n = 2 0 9 7 )}\right.\end{array}$ & OR (95\% CI) & $\boldsymbol{P}$ \\
\hline Urban area, $n$ & 440 & 1460 & $2.15(1.68-2.75)$ & $<0.0001$ \\
\hline Female sex, $n$ & 422 & 1057 & $3.88(3.08-4.87)$ & $<0.0001$ \\
\hline Age 35-64 years, $n$ & 375 & 1097 & $2.21(1.80-2.72)$ & $<0.0001$ \\
\hline Tobacco use, $n$ & 9 & 74 & $0.47(0.23-0.95)$ & 0.03 \\
\hline Alcohol consumption, $n$ & 164 & 671 & $0.95(0.77-1.17)$ & 0.66 \\
\hline Hormonal contraception, ${ }^{a} n$ & 23 & 76 & $1.00(0.62-1.61)$ & 0.98 \\
\hline BMI: Body Mass Index; OR: Odds Ratio; CI: Confidence Interval; ${ }^{a}$ Data for women only & &
\end{tabular}


Table 3: Anthropometric characteristics, overall and according residence in an urban or semi-urban area

\begin{tabular}{|c|c|c|c|c|c|c|c|}
\hline Variable & Total & Urban area & Semi-urban area & OR $(95 \% \mathrm{CI})$ & $P$ & $O R^{a}(95 \% C I)$ & $p^{\mathbf{a}}$ \\
\hline \multicolumn{8}{|l|}{ BMI, $n(\%)$} \\
\hline Underweight & $118(4.5)$ & $61(3.2)$ & 57 (7.9) & - & & - & - \\
\hline Normal & $1251(47.6)$ & $876(46.1)$ & 375 (51.7) & - & & - & - \\
\hline Overweight & 728 (27.7) & $523(27.5)$ & 205 (28.2) & - & & - & - \\
\hline Obese & $529(20.1)$ & $440(23.2)$ & $89(12.3)$ & $\begin{array}{c}2.15 \\
(1.68-2.75)\end{array}$ & $<0.0001$ & $\begin{array}{c}2.62 \\
(1.96-3.50)\end{array}$ & $<0.0001$ \\
\hline Moderate & $367(14.0)$ & 303 (15.9) & $64(8.8)$ & - & & - & - \\
\hline Severe & $116(4.4)$ & $101(5.3)$ & $15(2.1)$ & - & & - & - \\
\hline Morbid & $46(1.8)$ & $36(1.9)$ & $10(1.4)$ & - & & - & - \\
\hline
\end{tabular}

Waist circumference (NCEP), ${ }^{\mathrm{b}} n / N(\%)$

\begin{tabular}{|c|c|c|c|c|c|c|c|}
\hline Normal & $1234 / 1862(66.3)$ & $\begin{array}{c}933 / 1416 \\
(65.9)\end{array}$ & $301 / 446(67.5)$ & & & & \\
\hline Central obesity & 628/1862 (33.7) & $\begin{array}{c}483 / 1416 \\
(34.1)\end{array}$ & $145 / 446(32.5)$ & $\begin{array}{c}1.07 \\
(0.85-1.34)\end{array}$ & 0.53 & - & - \\
\hline \multicolumn{8}{|c|}{ Waist circumference (IDF), ${ }^{\mathrm{c}} n / N(\%)$} \\
\hline Normal & $953 / 1862(51.2)$ & $\begin{array}{c}717 / 1416 \\
(50.6)\end{array}$ & $236 / 446(52.9)$ & & & - & - \\
\hline Central obesity & $909 / 1862(48.8)$ & $\begin{array}{c}699 / 1416 \\
(49.4)\end{array}$ & $210 / 446(47.1)$ & $\begin{array}{c}1.09 \\
(0.88-1.35)\end{array}$ & 0.40 & & \\
\hline
\end{tabular}

OR: Odds Ratio; CI: Confidence Interval; BMI: Body Mass Index; NCEP: National Cholesterol Education Program; IDF: International diabetes Federation

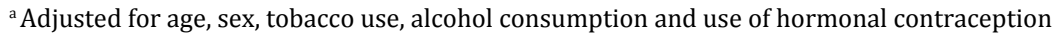

b $>88 \mathrm{~cm}$ for women and $102 \mathrm{~cm}$ for men [21]

c $>80 \mathrm{~cm}$ for women and $>94 \mathrm{~cm}$ for men $[22]$

\begin{tabular}{|c|c|c|c|c|c|c|}
\hline Variable & Women $(n=1479)$ & $\operatorname{Men}(n=1147)$ & OR (95\% CI) & $P$ & $\mathbf{O R}^{\mathbf{a}}$ & $p^{a}$ \\
\hline \multicolumn{7}{|l|}{ BMI, $n(\%)$} \\
\hline Normal weight & $561(37.9)$ & $690(60.2)$ & & & - & - \\
\hline Overweight & $433(29.3)$ & $295(25.7)$ & & & - & - \\
\hline Obese & $422(28.5)$ & $107(9.3)$ & $3.88(3.08-4.87)$ & $<0.0001$ & $4.46(3.31-6.00)$ & $<0.0001$ \\
\hline Moderate & $279(18.9)$ & $88(7.7)$ & & & - & - \\
\hline Severe & $99(6.7)$ & $17(1.5)$ & & & - & - \\
\hline Morbid & $44(3.0)$ & $2(0.2)$ & & & - & - \\
\hline \multicolumn{7}{|c|}{ Waist circumference (NCEP), ${ }^{\mathrm{b}} n / N(\%)$} \\
\hline Normal & $484 / 1043(46.4)$ & $750 / 819(91.6)$ & & & & \\
\hline Central obesity & $559 / 1043(53.6)$ & $69 / 819(8.4)$ & $12.5(9.5-16.5)$ & $<0.0001$ & $11.8(8.5-16.3)$ & $<0.0001$ \\
\hline \multicolumn{7}{|c|}{ Waist circumference (IDF), ${ }^{\mathrm{c}} n / N(\%)$} \\
\hline Normal & $320 / 1043(30.7)$ & $633 / 819(77.3)$ & & & & \\
\hline Central obesity & $723 / 1043 \quad(69.3)$ & $186 / 819$ (22.7) & $7.68(6.23-9.48)$ & $<0.0001$ & $9.32(7.09-12.24)$ & $<0.0001$ \\
\hline \multicolumn{7}{|c|}{$\begin{array}{l}\text { OR: Odds Ratio; CI: Confidence Interval; BMI: Body Mass Index; NCEP: National Cholesterol Education Program; IDF: International Diabetes Federation } \\
{ }^{a} \text { Adjusted for age, location of residence, tobacco use, alcohol consumption and use of hormonal contraception } \\
\text { b }>88 \mathrm{~cm} \text { for women and }>102 \mathrm{~cm} \text { for men [21] } \\
{ }^{\mathrm{c}}>80 \mathrm{~cm} \text { for women and }>94 \mathrm{~cm} \text { for men }[22]\end{array}$} \\
\hline
\end{tabular}

Citation: Komlavi Yayehd, Marie Paule Bernadette N'cho-Mottoh, et al. (2017) Prevalence and Determinants of Adult Obesity in a LowIncome Population of Western Africa: Results from a Nationwide Cross-Sectional Survey. Obes Control Ther 4(2):1-9. 
Table 5: Comparison of anthropometric data in women and men residing in urban and semi-urban areas

\begin{tabular}{|c|c|c|c|c|c|c|}
\hline \multirow{2}{*}{ Variable } & \multicolumn{3}{|c|}{ Urban area $(n=1900)$} & \multicolumn{3}{|c|}{ Semi-urban area $(n=726)$} \\
\hline & Women $(n=1028)$ & $\operatorname{Men}(n=872)$ & $p$ & Women $(n=451)$ & $\operatorname{Men}(n=275)$ & $\mathbf{p}$ \\
\hline \multicolumn{7}{|l|}{ BMI, $n(\%)$} \\
\hline Underweight & $27(2.6)$ & $34(3.9)$ & & $36(8.0)$ & $21(7.6)$ & \\
\hline Normal weight & $355(34.5)$ & $521(59.7)$ & & $206(45.7)$ & $169(61.5)$ & \\
\hline Overweight & $300(29.2)$ & $223(25.6)$ & & $133(29.5)$ & $72(26.2)$ & \\
\hline Obese & $346(33.7)$ & $94(10.8)$ & $<0.0001$ & $76(16.9)$ & $13(4.7)$ & $<0.0001$ \\
\hline Moderate & $227(22.1)$ & $76(8.7)$ & & $52(11.5)$ & $12(4.4)$ & \\
\hline Severe & $85(8.3)$ & $16(1.8)$ & & $14(3.1)$ & $1(0.4)$ & \\
\hline Morbid & $34(3.3)$ & $2(0.2)$ & & $10(2.2)$ & 0 & \\
\hline \multicolumn{7}{|c|}{ Waist circumference (NCEP), ${ }^{a} n / N(\%)$} \\
\hline Normal & $330 / 752(43.9)$ & $603 / 664(90.8)$ & $<0.0001$ & $137 / 291(47.1)$ & $8 / 155(5.2)$ & $<0.0001$ \\
\hline Central obesity & $422 / 752(56.1)$ & $61 / 664(9.2)$ & & $154 / 291(52.9)$ & $147 / 155(94.8)$ & \\
\hline \multicolumn{7}{|c|}{ Waist circumference (IDF), ${ }^{\mathrm{b}} n / N(\%)$} \\
\hline Normal & $209 / 752(27.8)$ & $508 / 664(76.5)$ & $<0.0001$ & $111 / 291(38.1)$ & $125 / 155(80.6)$ & $<0.0001$ \\
\hline Central obesity & $543 / 752(72.2)$ & $156 / 664(23.5)$ & & $180 / 291(61.9)$ & $30 / 155(19.4)$ & \\
\hline
\end{tabular}

These differences persisted after adjustment for age, location of residence, tobacco use, alcohol consumption and use of hormonal contraception (Table 4).

Sex-related differences in anthropometric data for the urban and semi-urban populations are detailed in Table 5. Women were more often obese than men in both the urban and semi-urban areas (both $\mathrm{p}<0.0001$ ), whereas men were more likely to have a BMI indicating normal weight.

\section{Discussion}

The data from this cross-sectional survey show that the prevalence of adult obesity in a low-income population in Western Africa is $20.1 \%$ and the most obese groups were women, those age 35-64 years and subjects living in an urban area.

The prevalence of adult obesity in Togo is as high as that reported in other Western African countries such as Nigeria $(19.6 \%)$ or Ghana (17.1\%), and in Lebanon (18-22\%) $[27,28,12,2]$. Whereas the rate in Togo is lower than the prevalence of $34.9 \%$ reported in the United States of America (USA) in the same period, the difference is not that great, which is a concern considering that the USA has one of the greatest rates of obesity in the world [29]. Furthermore, Western African countries that face other health challenges - such as infectious diseases and malnutrition - do not have sufficient health budgets to deal with the consequences of obesity. In comparison, some developed countries - such as France - have a modest prevalence of obesity (15\%), even if that of overweight is high, at 32.3\% [30]. Over the past three decades, the prevalence of obesity has increased worldwide, in both developed and developing countries [3].

We reported high prevalence of obesity among urban populations compared to semi-urban ones; this finding has been reported in another Western African country [16]. Indeed, Higher prevalence of overweight (27.2\% vs $16.7 \%)$ and obesity $(20.6 \%$ vs $8.0 \%)$ were estimated for urban than rural dwellers in a recent meta-analysis in Ghana [31]. In the same region, urban residence was strongly associated with obesity with an odd ratio of 7.8 (95\% CI: $5.3 \pm 11.3$ ) [17].Many reasons may explain the discrepancy in the prevalence of obesity among urban and semiurban populations in Western Africa. First, physical inactivity, a high-calorie diet and low consumption of vegetables and fruits are common among urban populations in developing countries. According to the WHO, increased urbanization, car dependence and sedentary occupations are greatly contributing to the global obesity epidemic [32]. Second, alcohol consumption was more prevalent in urban populations. Alcohol consumption may lead to overeating episodes and highly impulsive individuals may be 
at risk for increased energy intake during or after episodes of drinking ("binge eating") [24]. Thus, alcohol may contribute to an increase in body weight associated with a certain drinking pattern [33]. Third, as medical care is easily accessible in the urban area of Lomé, the use of hormonal contraceptives was more common. It is suspected that the use of these contraceptives increases the risk of obesity, and Black race is a significant predictor of weight gain among contraceptive users [25,34].

We also found that obesity was more prevalent in women compared with men; in the same way, the meta-analysis of Ofori-Asenso in Ghana reported a prevalence of obesity of $21.9 \%$ in women vs $6.0 \%$ in men [27]. Higher prevalence of obesity was also found among women in Tanzania (East Africa) [35]. Globally, sex-related patterns in the prevalence of obesity differ in developed versus developing countries. In a systematic analysis on the worldwide prevalence of obesity and overweight between 1980 and 2013, $\mathrm{Ng}$, et al. reported that, in developed countries, more men than women were overweight and obese, whereas overweight and obesity were more prevalent in women than in men in developing countries and this association persisted over time [3]. Lack of physical activity is common among African women and is one of the important risk factors for weight gain [36]. Sociologically, overweight or obese women are often valued in the African population; African women therefore need to be educated on the benefits of physical activity and on the health risks associated with obesity and overweight $[37,38]$

Finally, the question remains about which classification system for central obesity to use in African populations. If we consider the NCEP definition, the prevalence of abdominal obesity appears reasonable, but use of the IDF definition led to a high prevalence. It is uncertain whether the IDF definition of central obesity is suitable for the African population, as studies supporting this definition did not involve these populations. However, the IDF suggested using the cut-off of Europids for Africans [39]. More studies are needed in African populations to determine the precise cut-off for the definition of central obesity.

\section{Limitations}

This study may be subject to selection bias because subjects presented spontaneously to the screening after awareness sessions in the media; this type of bias is common to all such studies. However, the study population is likely to be representative because the proportion of women is close to that the general population ( $51.4 \%$ vs $48.6 \%$ of men), and all social strata were included [19]. Furthermore, the population included a high proportion $(90.7 \%)$ of the potentially active population aged 18-64 years and a small proportion of elderly subjects ( $\geq 65$ years), consistent with the profile of the Western African population [40]. The original aim of the survey was to determine the prevalence of hypertension in this population. Consequently, some data relevant to obesity were not collected (e.g. levels of physical activity and type of diet).

\section{Conclusions}

The prevalence of adult obesity in a low-income population of Western Africa is now closer to that of developed countries. This situation is likely to worsen health deficits in the countries that have not yet completed their epidemiological transition. Urban living, female sex and age 35-64 years were associated with obesity. These findings could be useful in obesityprevention programs to target at-risk populations.

\section{Acknowledgements}

Sophie Rushton-Smith and Jenny Lloyd (MedLink Healthcare Communications Limited) provided editorial support (funded by the authors).

\section{Sources of support}

Agents and materials from the public administration (public hospitals) were used for this study.

\section{Funding}

The survey was conducted by the "Programme National de Lutte contre les Maladies cardiovasculaires" (PNLMCV) and was funded by the Ministry of Health of Togo, which provided a grant for data collection.

\section{References}

1. Sniehotta FF, Dombrowski SU, Avenell A, Johnston M, McDonald S, Murchie P, et al. Randomised controlled feasibility trial of an evidenceinformed behavioural intervention for obese adults with additional risk factors. PLoS One. 2011;6(8):e23040. doi: 10.1371/journal. pone. 0023040

2. Spiegel AM, Alving BM. Executive summary of the Strategic Plan for National Institutes of Health Obesity Research. Am J Clin Nutr. 2005;82(1 Suppl):211S-214S.

3. Ng M, Fleming T, Robinson M, Thomson B, Graetz N, Margono C, et al. Global, regional, and national prevalence of overweight and obesity in children and adults during 1980-2013: a systematic analysis for the Global Burden of Disease Study 2013. Lancet. 2014;384(9945):766781. doi: 10.1016/S0140-6736(14)60460-8

4. Dudenbostel T, Ghazi L, Liu M, Li P, Oparil S, Calhoun DA. Body mass index predicts 24-hour urinary aldosterone levels in patients with resistant hypertension. Hypertension. 2016;68(4):995-1003.

5. Martin-Castellanos A, Barca FJ, Cabanas MD, Martin P, Garcia M, Munoz MA, et al. Obesity and anthropometric indicators in a sample of males with Acute Coronary Syndrome in a health area with inclusion of inmates: case-control study. Rev Esp Sanid Penit. 2015;17(1):20-29. doi: 10.4321/S1575-06202015000100004

6. Batty GD, Shipley MJ, Jarrett RJ, Breeze E, Marmot MG, Smith GD. Obesity and overweight in relation to organ-specific cancer mortality in London (UK): findings from the original Whitehall study. Int J Obes (Lond). 2005;29(10):1267-1274.

7. Li H, George DM, Jaarsma RL, Mao X. Metabolic syndrome and 
components exacerbate osteoarthritis symptoms of pain, depression and reduced knee function. Ann Transl Med. 2016;4(7):133. doi: 10.21037/atm.2016.03.48

8. Adams KF, Schatzkin A, Harris TB, Kipnis V, Mouw T, Ballard-Barbash $\mathrm{R}$, et al. Overweight, obesity, and mortality in a large prospective cohort of persons 50 to 71 years old. N Engl J Med. 2006;355(8):763778.

9. Maaten S, Kephart G, Kirkland S, Andreou P. Chronic disease risk factors associated with health service use in the elderly. BMC Health Serv Res. 2008;8:237. doi: 10.1186/1472-6963-8-237

10. Pessinaba S, Yayehd K, Pio M, Baragou R, Afassinou Y, Tcherou T, et al Obesity in cardiology consultation in Lome: prevalence and risk factors associated with cardiovascular disease - study in 1200 patients. Pan Afr Med J. 2012;12:99.

11. Baragou S, Djibril M, Atta B, Damorou F, Pio M, Balogou A. Prevalence of cardiovascular risk factors in an urban area of Togo: a WHO STEPSwise approach in Lome, Togo. Cardiovasc J Afr. 2012;23(6):309-312. doi: 10.5830/CVJA-2011-071

12. Maruf FA, Udoji NV. Prevalence and Socio-Demographic Determinants of Overweight and Obesity in a Nigerian Population. J Epidemiol 2015;25(7):475-481. doi: 10.2188/jea.JE20140099

13. Oguoma VM, Nwose EU, Skinner TC, Digban KA, Onyia IC, Richards RS. Erratum To: Prevalence of cardiovascular disease risk factors among a Nigerian adult population: relationship with income level and accessibility to CVD risks screening. BMC Public Health. 2015;15:891. doi: 10.1186/s12889-015-2101-y

14. Oluyombo R, Akinwusi PO, Olamoyegun MO, Ayodele OE, Fawale $\mathrm{MB}$, Okunola 00, et al. Clustering of cardiovascular risk factors in semi-urban communities in south-western Nigeria. Cardiovasc J Afr 2016;27(5):322-327. doi: 10.5830/CVJA-2016-024

15. Addo PN, Nyarko KM, Sackey SO, Akweongo P, Sarfo B. Prevalence of obesity and overweight and associated factors among financial institution workers in Accra Metropolis, Ghana: a cross sectional study. BMC Res Notes. 2015;8:599.

16. Obirikorang C, Osakunor DN, Anto EO, Amponsah SO, Adarkwa OK. Obesity and Cardio-Metabolic Risk Factors in an Urban and Rural Population in the Ashanti Region-Ghana: A Comparative CrossSectional Study. PLoS One. 2015;10(6):e0129494. doi: 10.1371/ journal.pone.0129494

17. Kodaman N, Aldrich MC, Sobota R, Asselbergs FW, Poku KA, Brown NJ, et al. Cardiovascular Disease Risk Factors in Ghana during the Rural-to-Urban Transition: A Cross-Sectional Study. PLoS One 2016;11(10):e0162753. doi: 10.1371/journal.pone.0162753

18. Yayehd K, Damorou F, Akakpo R, Tcherou T, N'Da NW, Pessinaba S, et al. Prevalence and determinants of hypertension in Lome (Togo): results of a screening in May 2011. Ann Cardiol Angeiol (Paris) 2013;62(1):43-50. doi: 10.1016/j.ancard.2012.09.006

19. IHSN (International Household Survey Network). Togo - Quatrième
Recensement général de la population et de l'habitat 2010

20. Obesity: preventing and managing the global epidemic. Report of a WHO consultation. World Health Organ Tech Rep Ser. 2000;894:i-xii, 1-253.

21. Executive Summary of the Third Report of The National Cholesterol Education Program (NCEP) Expert Panel on Detection, Evaluation, And Treatment of High Blood Cholesterol In Adults (Adult Treatment Panel III). JAMA. 2001;285(19):2486-2497.

22. Holt RI. International Diabetes Federation re-defines the metabolic syndrome. Diabetes Obes Metab. 2005;7(5):618-620.

23. Mancia G, De Backer G, Dominiczak A, Cifkova R, Fagard R, Germano $\mathrm{G}$, et al. Guidelines for the management of arterial hypertension: The Task Force for the Management of Arterial Hypertension of the European Society of Hypertension (ESH) and of the European Society of Cardiology (ESC). Eur Heart J. 2007;28(12):1462-1536. doi: 10.1093/eurheartj/ehm236

24. Kase CA, Piers AD, Schaumberg K, Forman EM, Butryn ML. The relationship of alcohol use to weight loss in the context of behavioral weight loss treatment. Appetite. 2016;99:105-111. doi: 10.1016/j. appet.2016.01.014

25. Schraudenbach A, McFall S. Contraceptive use and contraception type in women by body mass index category. Womens Health Issues. 2009;19(6):381-389. doi: 10.1016/j.whi.2009.08.002

26. Liao C, Gao W, Cao W, Lv J, Yu C, Wang S, et al. The association of cigarette smoking and alcohol drinking with body mass index: a crosssectional, population-based study among Chinese adult male twins. BMC Public Health. 2016;16(1):311.

27. Mallat S, Gerges Geagea A, Jurjus RA, Rizkallah A, Oueidat A, Matar M et al. Obesity in Lebanon: A National Problem. World J Cardiovasc Dis. 2016;6(6):166-174.

28. Haddad FG, Brax H, Zein E, Abou El Hessen T. Obesity and related diseases in a Lebanese medical center. J Med Liban. 2006;54(3):152155 .

29. Ogden CL, Carroll MD, Kit BK, Flegal KM. Prevalence of childhood and adult obesity in the United States, 2011-2012. JAMA. 2014;311(8):806814. doi: 10.1001/jama.2014.732

30. ObÉpi. Enquête épidémiologique nationale sur le surpoids et l'obésité. Une enquête INSERM / KANTAR HEALTH / ROCHE. 2012.

31. Ofori-Asenso R, Agyeman AA, Laar A, Boateng D. Overweight and obesity epidemic in Ghana-a systematic review and meta-analysis. BMC Public Health. 2016;16(1):1239.

32. Vandevijvere S, Chow CC, Hall KD, Umali E, Swinburn BA. Increased food energy supply as a major driver of the obesity epidemic: a global analysis. Bull World Health Organ. 2015;93(7):446-456. doi: 10.2471/ BLT.14.150565

33.T VS, Ramadurg UY, Dorle AS, Ghattargi CH, Banada J. A CrossSectional Study on Pattern of Alcohol Consumption and Body Mass 
Index Among Health Institution Students in Bagalkot. J Clin Diagn Res. 2015;9(12):LC06-9. doi: 10.7860/JCDR/2015/15269.6905

34.Vickery Z, Madden T, Zhao Q, Secura GM, Allsworth JE, Peipert JF. Weight change at 12 months in users of three progestin-only contraceptive methods. Contraception. 2013;88(4):503-508. doi: 10.1016/j.contraception.2013.03.004

35. Shayo GA, Mugusi FM. Prevalence of obesity and associated risk factors among adults in Kinondoni municipal district, Dar es Salaam Tanzania. BMC Public Health. 2011;11:365. doi: 10.1186/1471-2458-11-365

36. Dwyer-Lindgren L, Freedman G, Engell RE, Fleming TD, Lim SS, Murray CJ, et al. Prevalence of physical activity and obesity in US counties, 2001-2011: a road map for action. Popul Health Metr. 2013;11:7. doi: 10.1186/1478-7954-11-7
37. Renzaho AM. Fat, rich and beautiful: changing socio-cultural paradigms associated with obesity risk, nutritional status and refugee children from sub-Saharan Africa. Health Place. 2004;10(1):105-113.

38. BeLue R, Okoror TA, Iwelunmor J, Taylor KD, Degboe AN, Agyemang $\mathrm{C}$, et al. An overview of cardiovascular risk factor burden in subSaharan African countries: a socio-cultural perspective. Global Health. 2009;5:10. doi: 10.1186/1744-8603-5-10

39. The IDF consensus worldwide definition of the metabolic syndrome.

40. Pyramides des âges pour le monde entier de 1950 à 2100 . Afrique de l'ouest 2016. 